\title{
Dietary and Hormonal Regulation of Aldolase B Gene Expression
}

Amold Munnich, Claude Besmond, Sylviane Darquy, Gérard Reach, Sophie Vaulont, Jean-Claude Dreyfus, and Axel Kahn Unité INSERM U-129, 75674 Paris Cédex 14, and Unité INSERM U-83, 75010 Paris, France

\section{Abstract}

Aldolase $B$ is an enzyme of the glycolytic pathway whose activity and mRNA levels in the liver fluctuate according to dietary status. Both the enzyme activity and the mRNA concentration decline during fasting and increase four- to eightfold upon refeeding of a carbohydrate-rich diet. The mechanism, however, of the mRNA induction remains unknown.

To elucidate the mechanisms that regulate this induction responsive to dietary stimuli, we have studied the roles of hormones and glycolytic substrates on aldolase $B$ gene expression in three tissues that synthesize the enzyme. Using a cDNA probe complementary to rat aldolase $B$ mRNA, we determined the amount of cytoplasmic RNAs in the liver, kidney, and small intestine of normal, adrenalectomized, thyroidectomized, diabetic, and glucagon- or cAMP-treated animals refed either a fructose-rich or a maltose-rich diet. The in vivo hormonal control of gene expression was found to be very different in the three organs tested. In the liver, cortisone and thyroid hormones were required for the induction of the specific mRNA by carbohydrates, while in the kidney none of the hormonal modifications tested altered the level of mRNA induction. In the liver, but not in the kidney, diabetes and glucagon administration abolished the induction of aldolase $B$ mRNAs in animals refed the maltose-rich diets. In the small intestine, only diabetes and thyroidectomy affected the gene expression. Finally, no induction occurred when normal fasted rats were given any of the hormones.

Thus, the in vivo hormonal control of liver aldolase $B$ gene expression differs significantly from that of kidney and small intestine. In the liver, the mRNA induction requires the presence of dietary carbohydrates, of permissive hormones, and the cessation of glucagon release, while in the kidney, the induction of the mRNAs by fructose occurs regardless of the hormonal status of the animals. The hormonal control of aldolase B mRNA levels in the small intestine is intermediate.

\section{Introduction}

Aldolase (fructose 1,6 diphosphate D-glyceraldehyde 3 phosphate lyase; EC 4.1.2.13) is an enzyme of the glycolytic pathway that exists in three distinct molecular forms, referred to as type A (muscle), B (adult liver) and C (brain). The three isozymes act on the common substrate, fructose 1,6 diphosphate (FDP) ${ }^{1}$ but differ in several characteristics, the most important

Address reprint requests to Dr. Munnich, Unité INSERM U-129, Institut de Pathologie Moléculaire, 75674 Paris Cedex 14.

Received for publication 30 July 1984 and in revised form 16 October 1984.

1. Abbreviations used in this paper: $\mathrm{Bt}_{2} \mathrm{CAMP}, \mathrm{N}^{6}, \mathrm{O}^{2}$-dibutyryl cAMP; FDP, fructose 1,6 diphosphate; F1P, fructose 1-phosphate; IRI, immunoreactive insulin; Poly A, polyadenylated; SSC, standard saline citrate.

J. Clin. Invest.

(c) The American Society for Clinical Investigation, Inc.

0021-9738/85/03/1045/08 $\$ 1.00$

Volume 75, March 1985, 1045-1052 being their relative activity toward the other substrate, fructose 1-phosphate (F1P). While aldolase $A$ and $C$ are mainly active toward FDP, aldolase $B$ is equally active toward the two substrates FDP and F1P (1-6).

In adult liver, most of the aldolase activity is the result of aldolase B (7). Aldolase B is also found in kidney and small intestine, where it forms mixed multimers with aldolase $A(8)$. In both liver and small intestine, aldolase B activity (i.e., the activity toward the substrate F1P) fluctuates according to dietary status (9-15). During fasting, the activity of the enzyme rapidly declines, while refeeding of a carbohydrate-rich diet restores the enzyme activity $(9-15)$.

We have previously shown, using both the translational activities of the mRNAs and their specific hybridization with cloned cDNA probes, that aldolase B mRNA is low in the liver and small intestine of fasted rats $(16,17)$. Feeding fasted animals a sucrose-rich diet gives rise to a four- to eightfold increase of aldolase B mRNA in both liver and small intestine and to a 1.5- to 2.5-fold increase in the kidney, with a maximum increase at the 18 th $\mathrm{h}$ of the refeeding $(16,17)$.

Using a cDNA clone complementary to rat aldolase $B$ mRNA, we studied the respective roles of hormones and dietary carbohydrates in the induction of the specific mRNA in liver, kidney, and small intestine of animals refed a carbohydrate-rich diet. Neither adrenalectomized nor thyroidectomized nor diabetic animals expressed aldolase B mRNA in the liver when refed a maltose-rich diet. When the rats were given the missing hormone, the level of hybridizable mRNA returned to control values, but administration of the hormone alone failed to induce mRNA synthesis in fasted animals. Both glucagon and cAMP abolished the induction of aldolase B mRNA in refed animals. Thus, the synthesis of the liver mRNA requires the presence of dietary carbohydrates, the cessation of glucagon release, and the presence of permissive hormones including insulin.

In the small intestine of maltose-fed rats, the presence of both insulin and thyroid hormones was required as well, but glucagon and cAMP administration had no effect on the mRNA induction. Most interesting, diabetic animals could express the mRNA in both the liver and small intestine when refed the fructose-rich but not the maltose-rich diet. In the kidney, the synthesis of the mRNA was constitutive, poorly modulated by the diet, and unaffected by the hormonal status of the animals. Therefore, the dietary and hormonal control of the aldolase B gene expression strongly differed in the three organs tested.

\section{Methods}

\section{Materials}

Usual chemicals of the highest purity available were from Merck Chemical Div., Merck \& Co., Inc. Isotopes, Rahway, NJ; Sigma Chemical Co., St. Louis, MO; and Boehringer-Mannheim Biochemicals, Indianapolis, IN. Cortisone acetate was from Roussel Corp., New York, NY; 3,3',5-triiodo-L-thyronine, $\mathrm{N}^{6}, \mathrm{O}^{2}$-dibutyryl cAMP $\left(\mathrm{Bt}_{2} \mathrm{CAMP}\right)$, alloxan, and theophylline were purchased from Sigma Chemical Co. Regular insulin and zinc-protamine insulin were from 
Choay Laboratory, Paris, France. Long-acting glucagon (zinc-glucagon and zinc-protamine-glucagon) was a gift from Novo Industries, Paris, France. DEAE membranes and nitrocellulose paper (BA85) were obtained from Schleicher \& Schuell, Inc., Keene, NH. Formaldehyde was from Flucka A.G., Basel, Switzerland. $\left[\alpha{ }^{32} \mathrm{P}\right] \mathrm{dCTP}(3,000 \mathrm{Ci} /$ mmol) and restriction enzymes were supplied by Amersham Corp., Arlington Heights, IL, and Biofluor by New England Nuclear, Boston, MA. Royal-X-Omat A.R. films were purchased from Eastman Kodak Co., Rochester, NY.

Animals. 3-mo-old male Wistar rats weighing $\sim 250 \mathrm{~g}$ were housed in individual cages. They were deprived of food for $48 \mathrm{~h}$, from 3:00 $\mathrm{pm}$ to $3: 00 \mathrm{pm}$. Then all rats were refed either the maltose-rich or the fructose-rich diet for $18 \mathrm{~h}$, from 3:00 pm to 9:00 am on the next day. The carbohydrate-rich diet was an artificial solid diet containing $95 \%$ of either fructose or glucose (glucose $12 \%$, maltose $15 \%$, tri- to heptaholosides $38 \%$, and polyholosides $30 \%$ ) and $5 \%$ of proteins and minerals. $40 \mathrm{~g}$ of the solid diet in individual heavy cups was introduced in the cages. Carbohydrate was also given in water containing $200 \mathrm{~g} /$ liter of the appropriate sugar. The accurate sugar consumption was determined by weighing food and measuring water before and after refeeding. All rats ate adequately after refeeding and the diet was well tolerated. The carbohydrate consumption of each group of animals is given in Table $\mathrm{I}$.

Some animals underwent bilateral adrenalectomy or thyroparathyroidectomy under pentobarbital anesthesia $(65 \mathrm{mg} / \mathrm{kg}), 8 \mathrm{~d}$ and $5 \mathrm{wk}$ before starvation, respectively, as described (18).

ADX rats were maintained on $1 \%$ sodium chloride as the drinking water. Some animals were treated with cortisone acetate $(10 \mathrm{mg})$ intraperitoneally twice a day $24 \mathrm{~h}$ before exsanguination. Evidence for adrenalectomy was provided by measuring blood corticosterone. Levels were (mean $\pm 1 \mathrm{SD}) 1.7 \pm 0.8 \mathrm{ng} / \mathrm{ml}$ for operated on animals $(n=15)$ and $160 \pm 20 \mathrm{ng} / \mathrm{ml}$ for controls (between 9:00 a.m. and 11:00 a.m., Fondation de Recherches en Hormonologie, Paris).

Thyroparathyroidectomized rats had their thyroid removed without injury to the recurrent nerve. Then, they were maintained on $1 \%$ calcium chloride as the drinking water. Those animals that were treated received one single dose of triiodo-L-thyronine $(50 \mu \mathrm{g})$ intraperitoneally $1 \mathrm{~h}$ before refeeding. Evidence for thyroidectomy was provided by measuring, in thyroidectomized animals $(n=6)$ as compared with normal controls, blood triiodo-L-thyronine $(0.7 \pm 0.1 \mathrm{nmol} /$ liter, control $=1.4 \pm 0.1 \mathrm{nmol} /$ liter $)$, thyroxin $(13.6 \pm 11 \mathrm{nmol} / \mathrm{liter}$, controls $=70 \pm 7 \mathrm{nmol} / \mathrm{liter})$, and thyrostimulin hormone $(7.5 \pm 3.4$ $\mu \mathrm{U} / \mathrm{ml}$, range $4.5-11$, controls below $2 \mu \mathrm{U} / \mathrm{ml}$ ) by the radioimmunological method.

Diabetes was induced by intravenous injection of alloxan $(30 \mathrm{mg} /$ rat) after starvation for $24 \mathrm{~h}$. Blood glucose was assayed $2 \mathrm{~d}$ after alloxan injection using the glucose oxidase method, and those animals whose blood glucose exceeded $15 \mathrm{mmol} /$ liter were used for experiments.

Long-acting glucagon $(0.4-1.5 \mathrm{mg} / \mathrm{kg}$ per $18 \mathrm{~h}$ ) was administered in two injections during the 18 -h period of refeeding (19). The drug was given both intraperitoneally (zinc-glucagon) and subcutaneously (zinc-protamine-glucagon) to obtain a rapid and sustained hormonal impregnation over the 18 -h period of refeeding. In some rats, insulin (regular + long-acting) was administered subcutaneously together with long-acting glucagon (5 $\mathrm{U}$ each).

Rapid glucagon $(0.5 \mathrm{mg} / \mathrm{kg}$ per $\mathrm{h})$, theophylline $(0.5 \mathrm{mg} / \mathrm{kg}$ per $\mathrm{h})$, $\mathrm{Bt}_{2}$ CAMP $(0.2-20 \mathrm{mg} / \mathrm{kg}$ per $\mathrm{h})$, and arginine $(10 \mathrm{mM})$ alone or in combination were continuously administered in a $0.9 \%$ sodium chloride solution at a $0.5 \mathrm{ml} / \mathrm{h}$ flow rate over the 18 -h period of refeeding. To deliver continuous infusion, the femoral vein was cannulated as described (20). The animals were starved for $2 \mathrm{~d}$ after surgery then refed under continuous infusion. They could move about freely to obtain food and water, but they could not gain access to the cannula or disturb the perfusion procedure.

The food consumption of adrenalectomized, thyroidectomized, diabetic, glucagon, or cAMP- and theophylline-treated rats matched that of normal fed controls (Table I).

The rats were sacrificed by decapitation and blood was taken for plasma glucose and hormone determination. Food ingestion to the stomach and gut was checked by postmortem examination, and the whole liver, the kidneys, and the small intestine (from pylora to ileum) were removed and weighed. The animals were considered correctly refed when their food consumption, blood glucose and insulin levels, and their liver weight matched that of fed controls (Table I).

\section{Methods}

$R N A$ isolation and polyadenylated (poly A) RNA quantitation. Rat liver, kidneys, and small intestine (from pylora to ileum) were homogenized in a $7-\mathrm{M}$ guanidium chloride solution at $\mathrm{pH} 5$, containing $0.5 \%$ (wt/vol) lauroyl sarcosine and $10 \mathrm{mM}$ iodoacetate. Total cellular RNAs were extracted by ethanol precipitation in guanidium $\mathrm{HCl}$ as described (21). Poly A RNA concentration in the different cellular RNA preparations was measured by hybridization with $\left[{ }^{3} \mathrm{H}\right]$ polyuridylic acid as described (22).

Nick-translation of cloned cDNA probes complementary to aldolase $B$ mRNAs. Recombinant plasmids containing the cDNA complementary to aldolase B mRNAs were digested using the restriction enzyme Pst $I$ under conditions recommended by the suppliers. Then, the products of digestion were electrophoretically separated on a $1 \%$ agar gel and stained with $0.5 \mu \mathrm{g} / \mathrm{ml}$ of ethidium bromide. The cDNA inserts were electroblotted on a DEAE membrane using a Trans Blot Cell (BioRad Laboratories, Richmond, CA) then eluted and recovered by ethanol precipitation. The purified inserts were labeled with ${ }^{32} \mathrm{P}$ by Nick-translation $\left(\sim 8 \times 10^{7} \mathrm{cpm} / \mu \mathrm{g} \mathrm{sp}\right.$ act $)$.

Northern blot analysis and quantitation of aldolase $B$ mRNA content by dot-blot analysis. Total RNA was denatured in $10 \mathrm{mM}$ methylmercury hydroxide for $10 \mathrm{~min}$ at $20^{\circ}$ then applied to a $1.5 \%$ agar gel containing $10 \mathrm{mM}$ methylmercury hydroxide in a $5-\mathrm{mM}$ sodium tetraborate buffer, $10 \mathrm{mM}$ sodium sulfate, $1 \mathrm{mM}$ EDTA, and $50 \mathrm{mM}$ boric acid $\mathrm{pH} 8.2$ and separated by electrophoresis for $3 \mathrm{~h}$ (23). The gel was then washed and transferred to nitrocellulose in 20X standard saline citrate (SSC; $1 \mathrm{SSC}=0.15 \mathrm{M}$ sodium chloride, 0.015 $\mathrm{M}$ trisodium citrate) for at least $12 \mathrm{~h}$. The nitrocellulose filters were then baked and hybridized as described $(17,23,24)$.

The dot-blot procedure was used for measuring specific mRNA concentration. Nitrocellulose filters were cross-ruled in squares of 1 $\mathrm{cm}^{2}$, prewet in sterile water, then soaked in 20X SSC and allowed to dry in air. Total RNA was diluted in $10 \mathrm{mM}$ phosphate buffer, $\mathrm{pH}$ 7.4 , and its concentration was checked by measuring $O D$ at $260 \mathrm{~nm}$. Then, RNA was denatured in $2.2 \mathrm{M}$ formaldehyde for $10 \mathrm{~min}$ at $65^{\circ} \mathrm{C}$. $4 \mu \mathrm{g}$ of RNA and five subsequent $1: 2$ dilutions in $10 \mathrm{mM}$

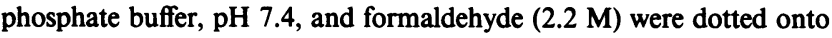
nitrocellulose filter squares using digital adjust micro/pettor (1-6 $\mu \mathrm{l}$; Scientific Manufacturing Ind., Emeryville, CA). The final volume dotted depended on the accurate concentration of the RNAs and was $\sim 3 \pm 0.3 \mu \mathrm{l}$. The hybridization was performed in $3 \mathrm{SSC}$ at $65^{\circ} \mathrm{C}$ in the presence of $10 \%$ sulfate dextran, $0.1 \%$ sodium dodecyl sulfate, $0.2 \%$ ficoll, $0.2 \%$ polyvinylpyrrolidone, $0.2 \%$ glycine, and in the presence of $10^{6} \mathrm{cpm} / \mathrm{ml}$ of labeled purified inserts $(0.5 \mathrm{ml}$ hybridization mixture/ $10 \mathrm{~cm}^{2}$ of filter surface). After autoradiographic exposure, the dots were cut out and counted by liquid scintillation. Radioactivity was linear with RNA amount dotted onto the filter. The results were expressed in counts per minute of hybridized probe per $4 \mu \mathrm{g}$ of dotted RNA. Assay blanks were prepared using RNAs derived from two organs devoid of aldolase B (spleen and lung); the radioactivity counted was $\sim 0$.

There is $67 \%$ homology between rabbit aldolase $\mathrm{A}$ and rat aldolase $B$ at the amino acid level (25). However, in the conditions of hybridization and washing stringency used here, no hybridization occurs between rat aldolase A and B cDNAs (Mennecier, F., and F. Schweighoffer, unpublished data). Therefore, aldolase B cDNA cannot recognize aldolase A mRNA in our stringent conditions (26).

\section{Results}

Dietary control of aldolase B gene expression in liver, kidney, and small intestine. In the liver and small intestine of normal 
Table I. Dietary Control of Aldolase B Gene Expression

\begin{tabular}{|c|c|c|c|c|c|c|c|}
\hline $\begin{array}{l}\text { Carbohydrate consumption, } \\
\text { insulin and liver weight } \\
\text { levels, and RNA recovery }\end{array}$ & $\begin{array}{l}\text { Normal } \\
\text { fasted } \\
n=3\end{array}$ & $\begin{array}{l}\text { Normal } \\
\text { fed } \\
n=7\end{array}$ & $\begin{array}{l}\text { ADX fed } \\
n=15\end{array}$ & $\begin{array}{l}\text { TX fed } \\
n=6\end{array}$ & $\begin{array}{l}\text { Diabetic } \\
\text { fed } \\
n=4\end{array}$ & $\begin{array}{l}\text { Fed }+\mathrm{Bt}_{2} \\
\text { cAMP } \\
n=6\end{array}$ & $\begin{array}{l}\text { Fed } \\
+ \text { glucagon } \\
n=16\end{array}$ \\
\hline $\begin{array}{l}\text { Sugar consumption } \\
\qquad(g / 18 h)\end{array}$ & 0 & $\begin{array}{r}13.4 \\
\pm 3.4\end{array}$ & $\begin{array}{r}10 \\
\pm 2\end{array}$ & $\begin{array}{r}12.6 \\
\pm 2.5\end{array}$ & $\begin{array}{r}13.1 \\
\pm 7.4\end{array}$ & $\begin{array}{l}16.5 \\
\pm 5\end{array}$ & $\begin{array}{r}17.3 \\
\pm 5.4\end{array}$ \\
\hline $\begin{array}{l}\text { Blood glucose } \\
(\mathrm{mmol} / \mathrm{liter})\end{array}$ & $\begin{array}{r}4.1 \\
\pm 0.6\end{array}$ & $\begin{array}{r}5.9 \\
\pm 1.0\end{array}$ & $\begin{array}{r}6.5 \\
\pm 1.0\end{array}$ & $\begin{array}{r}7.1 \\
\pm 0.9\end{array}$ & $\begin{array}{r}24.9 \\
\pm 1.8\end{array}$ & $\begin{array}{r}9.0 \\
\pm 1.7\end{array}$ & $\begin{aligned} & 6.22 \\
\pm & 2.0\end{aligned}$ \\
\hline Blood insulin $(\mu U / m l)$ & $\begin{array}{r}16 \\
\pm 4\end{array}$ & $\begin{array}{r}50 \\
\pm 10\end{array}$ & $\begin{aligned} & 76 \\
& \pm 24 \\
&(54-103)\end{aligned}$ & $\begin{aligned} & 45 \\
& \pm 14 \\
&(35-69)\end{aligned}$ & $\begin{array}{l}13 \pm 6 \\
(4-19)\end{array}$ & $\begin{aligned} & 227 \\
& \pm 134 \\
&(68-422)\end{aligned}$ & $\begin{array}{l}148 \\
\pm 84 \\
(77-355)\end{array}$ \\
\hline Liver weight $(g)$ & $\begin{array}{r}4.5 \\
\pm 0.5\end{array}$ & $\begin{array}{r}8.5 \\
\pm 0.4\end{array}$ & $\begin{array}{r}8.6 \\
\pm 0.9\end{array}$ & $\begin{array}{r}7.25 \\
\pm 1.20\end{array}$ & $\begin{aligned} & 8.95 \\
\pm & 1.0\end{aligned}$ & $\begin{array}{r}8.0 \\
\pm 1.2\end{array}$ & $\begin{array}{r}6.35 \\
\pm 0.95\end{array}$ \\
\hline $\begin{array}{l}\text { Liver RNA recovery } \\
\text { ( } m g \text { total } R N A / g \\
\text { tissue) }\end{array}$ & $\begin{aligned} & 4.58 \\
\pm & 1.0\end{aligned}$ & $\begin{array}{r}2.49 \\
\pm 0.24\end{array}$ & $\begin{array}{r}2.76 \\
\pm 1.18\end{array}$ & $\begin{aligned} & 3.85 \\
\pm & 0.2\end{aligned}$ & $\begin{array}{r}2.2 \\
\pm 0.8\end{array}$ & $\begin{aligned} & 3.76 \\
\pm & 0.9\end{aligned}$ & $\begin{aligned} & 2.06 \\
& \pm 1\end{aligned}$ \\
\hline $\begin{array}{l}\text { Poly A RNA }(\mu \mathrm{g} / \mathrm{mg} \\
\quad \text { liver } R N A)\end{array}$ & 1.60 & 1.35 & 1.45 & 1.65 & 1.50 & 1.45 & 1.25 \\
\hline $\begin{array}{l}\text { Kidney RNA recovery } \\
\text { (mg total } R N A / g \\
\text { tissue) }\end{array}$ & $\begin{aligned} & 1.50 \\
\pm & 0.3\end{aligned}$ & $\begin{array}{r}1.30 \\
\pm 0.15\end{array}$ & $\begin{array}{r}1.35 \\
\pm 0.25\end{array}$ & $\begin{array}{r}2.30 \\
\pm 1.20\end{array}$ & $\begin{array}{r}1.9 \\
\pm 1.1\end{array}$ & $\begin{array}{r}2.1 \\
\pm 0.8\end{array}$ & $\begin{array}{r}2.0 \\
\pm 0.35\end{array}$ \\
\hline $\begin{array}{l}\text { Small intestine RNA } \\
\text { recovery (mg total } \\
R N A / g \text { tissue })\end{array}$ & $\begin{aligned} & 2.6 \\
\pm & 0.40\end{aligned}$ & $\begin{array}{r}1.50 \\
\pm 0.35\end{array}$ & $\begin{array}{r}2.30 \\
\pm 0.85\end{array}$ & $\begin{array}{r}2.35 \\
\pm 0.30\end{array}$ & $\begin{array}{r}3.4 \\
\pm 0.5\end{array}$ & $\begin{aligned} & 2.50 \\
\pm & 1.0\end{aligned}$ & $\begin{array}{r}2.25 \\
\pm 0.55\end{array}$ \\
\hline
\end{tabular}

Data are means \pm 1 SD. ADX, adrenalectomized; TX, thyroidectomized.

fasted rats, RNA recovery per gram of tissue was twice that found in normal rats fed the fructose-rich or the maltose-rich diet for $18 \mathrm{~h}$ (Table I). However, since the mean weight of the liver (Table I) and small intestine (not shown) in fasted rats was approximately half that in fed rats, the total RNA content of the tissues was similar in both situations. The ratio of poly A sequences in the total liver RNA remained constant, regardless of the dietary status of the animals (Table I); additionally, the weight and total RNA recovery in the kidney were largely unaffected by the dietary status.

Aldolase B mRNA was low in both liver and small intestine of fasted rats (Table I). Both the maltose-rich and the fructoserich diets induced maximum expression of aldolase $B$ mRNA in the two organs $(P<0.001)$ (Figs. 1 and 6$)$, results being similar to those obtained with the sucrose-rich diet (16).

Aldolase B mRNA was abundant in the kidney of fasted rats. The mRNA abundance was even higher in the kidney of fasted animals (Fig. 7) than in the liver of carbohydrate-fed animals. No significant induction of the mRNA in the kidney occurred when normal fasted rats were refed the maltose-rich diet for $18 \mathrm{~h}$ (Fig. 7). However, refeeding the rats the fructoserich diet gave rise to a 2.5- to 3-fold increase of the specific mRNA concentration $(P<0.001)$ (Fig. 7), results being similar to those obtained with the sucrose-rich diet (16).

Effect of bilateral adrenalectomy on the dietary induction of aldolase $B \mathrm{mRNA}$ in liver, kidney, and small intestine. Aldolase B mRNA was low in the liver of fasted adrenalectomized animals, even when treated with pharmacological doses of cortisone acetate (Figs. 1 and 5). While feeding fasted normal rats a carbohydrate-rich diet induced maximum expression of aldolase B mRNA in the liver, feeding fasted adrenalectomized rats either diet resulted in a very low induction of the mRNA, averaging $20 \%$ of normal controls ( $P$

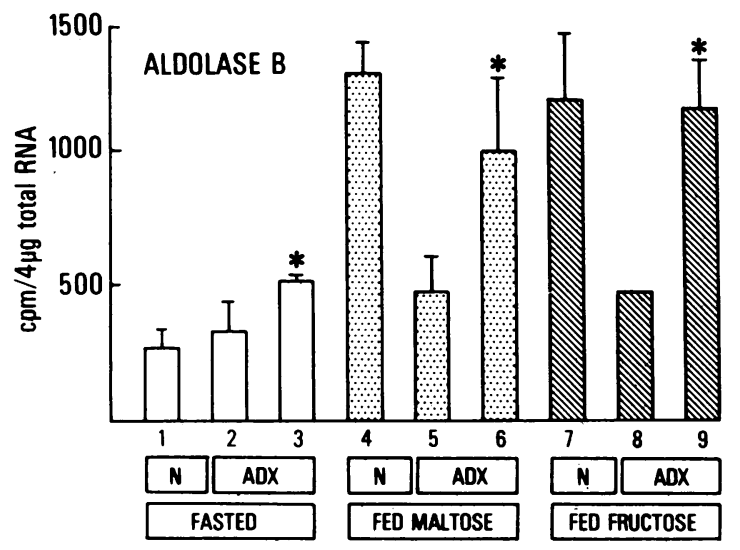

Figure 1. Effects of high carbohydrate diet, adrenalectomy, and cortisone on the level of aldolase $B$ mRNAs in rat liver. Total RNA was extracted from the liver of normal (N, bars 1, 4, and 7) and adrenalectomized (ADX) rats (bars 2, 3, 5, 6, 8, and 9), either starved (open bars 1-3), or refed the maltose-rich diet (dotted bars 4-6), or the fructose-rich diet (hatched bars 7-9) for $18 \mathrm{~h}$ after a $48 \mathrm{~h}$ fast. The asterisks on the tops of bars 3,6, and 9 indicate that the animals were given cortisone acetate as described in Methods. $4 \mu \mathrm{g}$ of RNA and five subsequent 1:2 dilutions were spotted onto the nitrocellulose filters in triplicate and analyzed by dot-blot hybridization as described in Methods. Data are means \pm 1 SD of nine individual determinations in three animals. 
$=0.001$ ) (Figs. 1 and 5). The food consumption, insulin release, total RNA content, and poly A RNA recovery in the liver of carbohydrate-fed adrenalectomized animals matched those of normal controls (Table I). When carbohydrate-fed adrenalectomized rats were given cortisone acetate, as described in Methods, the level of specific hybridization in the liver returned to normal values $(P<0.05)$ (Figs. 1 and 5).

On the other hand, refeeding of the carbohydrate-rich diet resulted in a normal induction of aldolase B mRNA in both kidney and small intestine of adrenalectomized animals (Figs. 6 and 7).

Effect of thyroparathyroidectomy on the dietary induction of aldolase $B$ mRNA in liver, kidney, and small intestine. Aldolase B mRNA was low in the liver of normal fasted rats, even when receiving pharmacological doses of triiodo-L-thyronine. When 48-h-fasted thyroidectomized animals were refed either the maltose-rich or the fructose-rich diet, the amount of hybridizable material in the liver was $\sim 20 \%$ of control values $(P<0.001)$ at the 18th h of the refeeding (Figs. 2 and 5). The food consumption, insulin release, total RNA content, and poly A RNA recovery in the liver matched those of fed controls (Table I). When thyroidectomized animals refed the carbohydrate-rich diet were given triiodo-L-thyronine, as described in Methods, the level of liver aldolase B mRNA returned to control values $(P<0.005)$ (Figs. 2 and 5). Similarly, no induction of the mRNA occurred in the small intestine of thyroidectomized animals refed either diet (Fig. 6). Thyroidectomy did not alter the fructose-rich dietary induction of mRNA in the kidney (Fig. 7).

Effect of diabetes on the dietary induction of aldolase $B$ $m R N A$ in liver, kidney, and small intestine. Regular insulin alone had no effect upon the level of aldolase B mRNA in either liver (Fig. 3), kidney (not shown), or small intestine (not shown), when continuously infused into $24-\mathrm{h}$-fasted rats for $6 \mathrm{~h}$ at $0.4 \mathrm{U} / \mathrm{h}$ flow rate (blood glucose level at the 6 th $\mathrm{h}$ of the infusion: $1.4 \mathrm{mmol} /$ liter).

When diabetic animals were given the maltose-rich diet for $18 \mathrm{~h}$, the level of liver and small intestine aldolase $B$ mRNA was very low $(P<0.001)$ and approximated that of

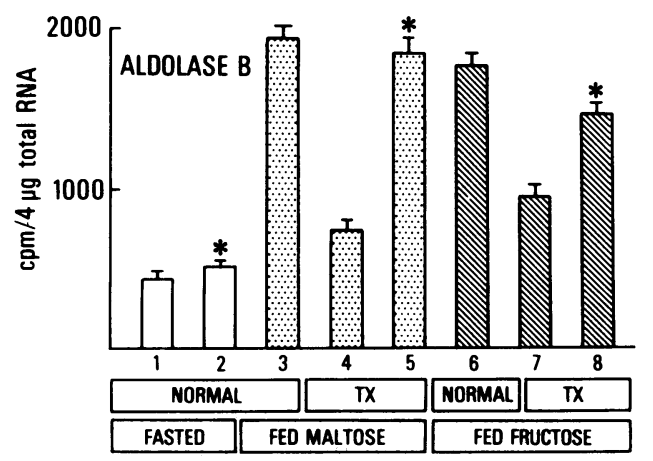

Figure 2. Effects of high-carbohydrate diet, thyroidectomy, and triiodo-L-thyronine on the level of aldolase B mRNAs in rat liver. Total RNA was extracted from the liver of normal (bars 1, 2, 3, and 6) and thyroidectomized (TX) rats (bars 4, 5, 7, and 8), either starved (open bars 1 and 2), or refed the maltose-rich diet (dotted bars 3-5) or the fructose-rich diet (hatched bars 6-8). The asterisks on the tops of bars 2, 5, and 8 indicate that the animals were given triiodo-Lthyronine as described in Methods. Data are the mean \pm 1 SD of nine individual determinations in three animals.

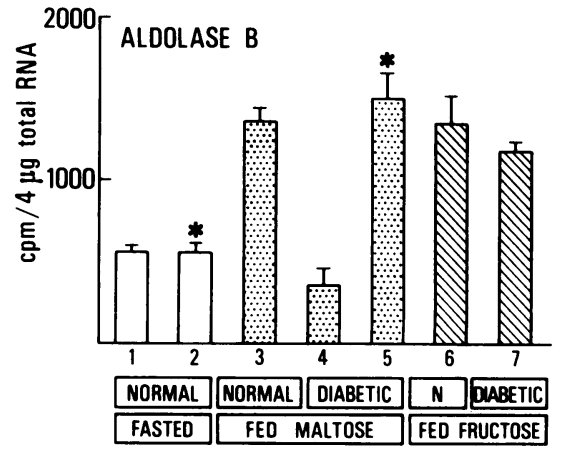

Figure 3. Effects of high-carbohydrate diet, diabetes, and insulin on the level of aldolase B mRNAs in rat liver. Total RNA was extracted from the liver of normal (bars 1-3,6) and diabetic rats (bars 4, 5, and 7), either fasted (bars 1 and 2) or fed the maltose-rich (bars 3-5) or the fructose-rich (bars 6 and 7) diet for $18 \mathrm{~h}$. The asterisks at the tops of bars 2 and 5 indicate that the diabetic animals were given insulin. 24-h fasted normal rats (bar 2) were given regular insulin (0.4 $\mathrm{U} / \mathrm{h}$ ) at a constant flow rate for $6 \mathrm{~h}$ only (see Methods).

fasted normal rats (Figs. 3, 5, and 6), although their food consumption and poly A RNA recovery matched those of fed normal controls (Table I). However, when diabetic animals fed the maltose-rich diet were given insulin (both regular and long-acting, $5 \mathrm{U}$ each twice a day), the level of hybridizable material returned to control values in both liver $(P<0.001)$ (Figs. 3 and 5) and small intestine (not shown). On the other hand, when diabetic animals were given the fructose-rich diet for $18 \mathrm{~h}$, the level of aldolase B mRNA in both liver and small intestine matched that of carbohydrate-fed normal controls (Figs. 3 and 6).

Finally, diabetes did not alter the induction of aldolase $B$ mRNA by the fructose-rich diet in the kidney (Fig. 7).

Effect of glucagon, $c A M P$, and arginine on the dietary induction of aldolase $B \mathrm{mRNA}$ in liver, kidney, and small intestine. 48-h-fasted normal rats were refed either the maltoserich or the fructose-rich diet under either regular or longacting glucagon administration for $18 \mathrm{~h}$ as described in Methods. In liver but not in kidney and small intestine, both regular and long-acting glucagon abolished the induction of aldolase B mRNA by the carbohydrate-rich diets $(P<0.001)$ (Fig. 4-7). cAMP mimicked the effects of glucagon when administered as $\mathrm{Bt}_{2} \mathrm{CAMP}$ at a constant flow rate, throughout the 18-h period of refeeding as described in Methods $(P<0.001)$. Theophylline, an inhibitor of phosphodiesterase activity, reduced the level of hybridizable material to the same extent. The effect of a physiological agent of glucagon release, arginine, was also tested. When normal rats were infused with $10 \mathrm{mM}$ arginine $(0.5 \mathrm{ml} / \mathrm{h})$ over the $18-\mathrm{h}$ period of the refeeding, the level of liver mRNA was reduced to $20 \%$ of controls $(P<0.001)$ (Fig. 4), while the level of kidney and small intestine mRNA matched that of carbohydrate-fed untreated controls (not shown).

Very high concentrations of immunoreactive insulin (IRI) were found in the plasma of glucagon- and $\mathrm{Bt}_{2} \mathrm{CAMP-treated}$ animals (Table I). Nevertheless, in spite of very high IRI concentrations in their plasma, neither endogenous nor exogenous insulin administered together with glucagon (Fig. 4) could reverse the effects of glucagon on the level of liver aldolase B mRNA. 


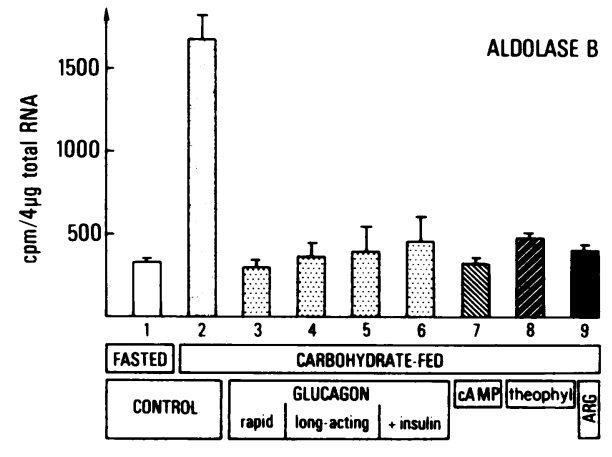

Figure 4. Effects of glucagon, $\mathrm{Bt}_{2} \mathrm{cAMP}$ (cAMP), arginine (ARG), and theophylline (THEOPHYL) on the level of aldolase B mRNAs in the liver of carbohydrate-fed animals. Either rapid-acting glucagon $(0.5 \mathrm{mg} / \mathrm{kg}$ per $\mathrm{h}$, bar 3$), \mathrm{Bt}_{2} \mathrm{cAMP}(0.2-20 \mathrm{mg} / \mathrm{kg}$ per h, bar 7$)$, theophylline $(0.5 \mathrm{mg} / \mathrm{kg}$ per $\mathrm{h}$, bar 8$)$, or arginine $(10 \mathrm{mM}$, bar 9$)$ were administered intravenously in a $0.9 \%$ sodium chloride solution at a $0.5 \mathrm{ml} / \mathrm{h}$ flow rate to 48 -h-fasted animals refed the maltose-rich diet, throughout the 18-h period of refeeding. Control rats (line 2) were given the saline solution intravenously at the same flow rate throughout the 18-h period of refeeding. Long-acting glucagon ( 0.4 $\mathrm{mg} / \mathrm{kg}$, bars 4-6) was administered in two injections over the 18-h period of refeeding, either alone (bars 4 and 5) or together with insulin (regular + long-acting insulin, $5 \mathrm{U}$ each, bar 6). The longacting glucagon-treated animals were refed either maltose (bars 4 and 6 ) or fructose (bar 5). Data are means \pm 1 SD of twelve individual determinations in six animals.

\section{Discussion}

The liver, and to a smaller extent the kidney and small intestine, are the main sites of fructose metabolism in mammals.

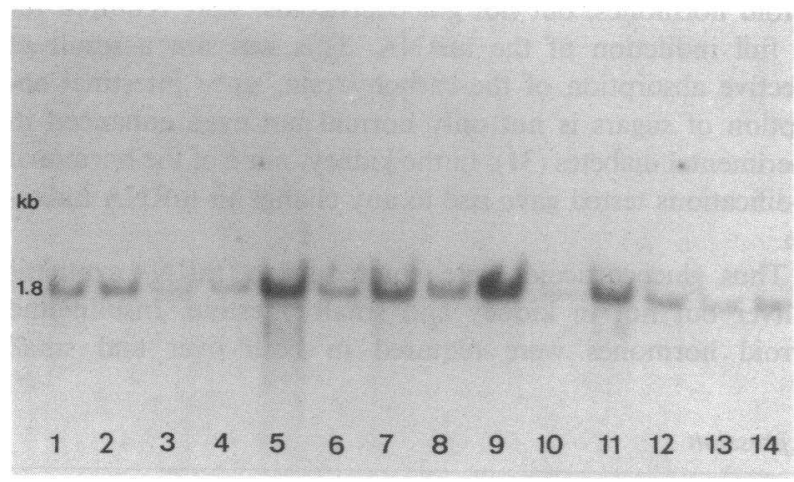

Figure 5. Northern blot analysis of liver aldolase B mRNAs derived from normal, adrenalectomized, thyroidectomized, diabetic, and glucagon- or $\mathrm{Bt}_{2} \mathrm{CAMP-treated} \mathrm{animals,} \mathrm{either} \mathrm{fasted} \mathrm{or} \mathrm{refed} \mathrm{the} \mathrm{mal-}$ tose-rich diet for $18 \mathrm{~h}$. 48-h-fasted normal rats, starved for 18 additional hours (lanes 1-4) were given either cortisone (lane 2), or triiodo-L-thyronine (lane 3) or no hormone (lane 1). Insulin (lane 4) was given for only $6 \mathrm{~h}$ to a $24-\mathrm{h}$-fasted animal. Other animals (lanes 5-14) were 48-h-fasted then refed the maltose-rich diet for $18 \mathrm{~h}$. Lane 5: normal fed rat, lane 6: adrenalectomized fed rat, lane 7: adrenalectomized fed rat + cortisone, lane 8: thyroidectomized fed rat, lane 9: thyroidectomized fed rat + triiodo-L-thyronine, lane 10: diabetic fed rat, lane 11: diabetic fed rat + insulin (10 U), lane 12: long-acting glucagon-treated $(100 \mu \mathrm{g})$ fed rat, lane 13: $\mathrm{Bt}_{2} \mathrm{CAMP}$ treated $(0.2 \mathrm{mg} / \mathrm{kg}$ per $\mathrm{h})$ fed rat, lane 14 : long-acting glucagon (100 $\mu \mathrm{g})+$ insulin $(5 \mathrm{U})$-treated fed rat. $15 \mu \mathrm{g}$ total RNA was deposited in each slot; electrophoresis was performed in methylmercury hydroxide-agarose gel as described in Methods.

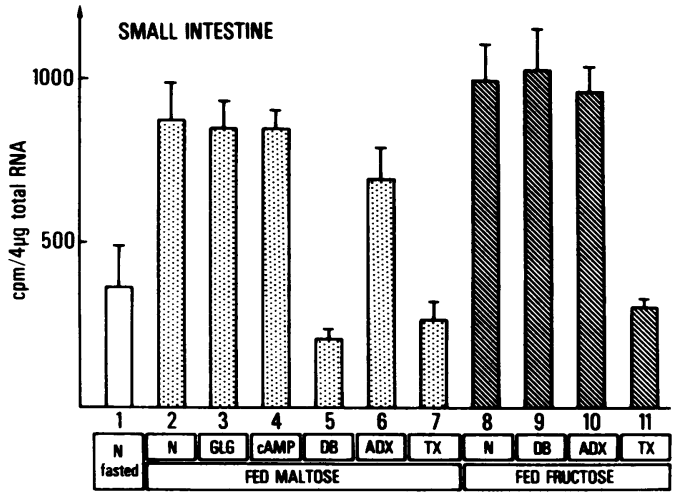

Figure 6. Effect of high-carbohydrate diet, glucagon (GLG), cAMP, diabetes (DB), adrenalectomy, and thyroidectomy on the level of aldolase B mRNA in rat small intestine. Total RNA was extracted from the small intestine of normal (bars 1, 2, and 8), glucagontreated (bar 3), cAMP-treated (bar 4), diabetic (bars 5 and 9), adrenalectomized (bars 6 and 10), or thyroidectomized (bars 7 and 11) animals, either fasted (bar 1) or fed the maltose-rich (bars 2-7) or the fructose-rich (bars 8-11) diet for $18 \mathrm{~h}$. Data are means \pm 1 SD of nine individual determinations in three animals.

These tissues possess a specialized pathway composed of three enzymes, fructokinase, aldolase $B$, and triokinase, that convert fructose to intermediates of the glycolytic-gluconeogenic pathway. Aldolase B is, therefore, a key enzyme of fructose metabolism via its highly specific activity toward the substrate F1P. Aldolase B is also involved in both the glycolytic and gluconeogenic pathways in the three tissues via its activity toward the substrates FDP and triose phosphates, respectively, but the enzyme is never rate-limiting, and the other two aldolases are active toward FDP as well.

Until recently, little was known regarding the dietary control of aldolase B expression. The liver enzyme decreased to $50 \%$ of its total activity as a result of fasting for $48 \mathrm{~h}$ and was completely restored in $24 \mathrm{~h}$ by either glucose or fructose feeding (9-11). The modifications were observed in total

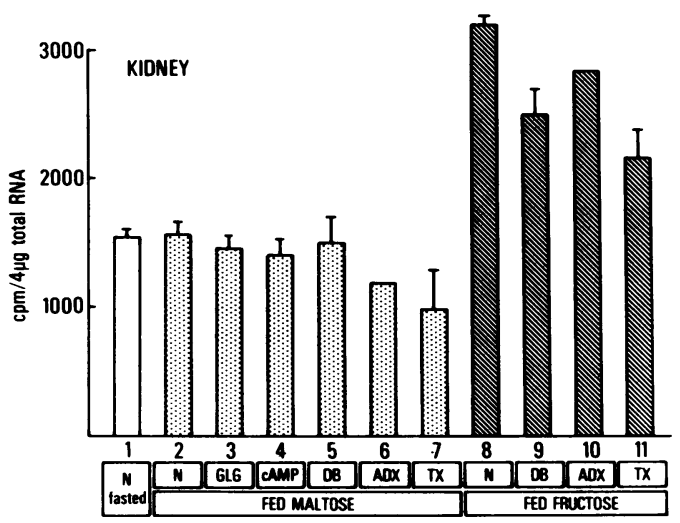

Figure 7. Effect of high-carbohydrate diet, glucagon, cAMP, diabetes, adrenalectomy, and thyroidectomy on the level of aldolase B mRNA in rat kidney. Total RNA was extracted from the kidney of normal (bars 1, 2, and 8), glucagon-treated (bar 3), cAMP-treated (bar 4), diabetic (bars 5 and 9), adrenalectomized (bars 6 and 10) or thyroidectomized (bars 7 and 11) animals, either fasted (bar 1) or fed the maltose-rich (bars 2-7) or the fructose-rich (bars 8-11) diet for $18 \mathrm{~h}$. Data are mean \pm 1 SD of nine individual determinations in three animals. 
activity, but specific activities of liver weight did not change greatly (9). Little was known regarding the dietary control of aldolase B expression in kidney and small intestine. Fructose feeding resulted in a three- to fourfold increase of enzyme activity in both rat $(12,13)$ and human $(14,15)$ small intestine, while glucose feeding caused a smaller but significant increase (12-15). On the other hand, aldolase B activity in kidney was found to be high regardless of the diet and was neither increased by fructose nor by glucose feeding (13).

Using both the translational activities of the mRNAs and their specific hybridization with cloned cDNA probes, we have recently shown that aldolase $B$ mRNA was low in both the liver and small intestine of fasted rats (16). Feeding fasted animals a carbohydrate-rich diet gave rise to a four- to eightfold increase of the mRNA in both the liver and small intestine, and to a 1.5- to 2.5-fold increase in the kidney, with a maximum increase at the 18 th $\mathrm{h}$ of refeeding (16).

In this study, the dietary conditions of the gene expression in both liver and small intestine are shown to be similar. The fructose-rich and the maltose-rich diets resulted in maximum induction of aldolase B mRNA in both the liver and small intestine of normal rats. In the kidney, the dietary regulation of the gene expression was considerably different: there was a high level of constitutive mRNA synthesis, which was only poorly modulated by the dietary status. The fructose-rich but not the maltose-rich diet gave rise to an increase of the mRNA level, results being similar to those obtained with the sucroserich diet (16). It is worth noting that the changes in the blood sugar concentration in the systemic circulation were mild in maltose-fed (Table I) but are very large in fructose-fed animals (27). On the other hand, carbohydrate flow in the portal circulation of the liver and small intestine is submitted to dramatic dietary modifications (28). This may account for the different in vivo responses of aldolase B mRNA to dietary carbohydrates in liver, kidney, and small intestine (Table II).

Very little is known regarding the hormonal control of aldolase B activity. In the liver, it has been reported that no recovery of the enzyme activity occurs in fasted adrenalectomized rats refed either a glucose-rich or a fructose-rich diet for $24 \mathrm{~h}$ (9). Essentially the same pattern has been found for hypophysectomized as for adrenalectomized rats (9). Thus, glucocorticoids were thought to be required for the adaptive response of liver aldolase B activity to dietary carbohydrates.
Schapira et al. (29) and Guguen-Guillouzo et al. (30) showed that the glucocorticoid dexamethasone increased the level of aldolase B activity in fetal liver cell culture, thus providing indirect evidence for a role of glucocorticoids in enzyme synthesis. On the other hand, alloxan-diabetes was reported to have no effect on aldolase B activity in the liver. However, animals were refed a stock not a carbohydrate-rich diet, so no conclusion can be drawn from these results (9). Consequently, aside from what has been learned from the results of adrenalectomy, the hormonal mechanisms that control the dietary induction of aldolase B in liver, kidney, and small intestine remain totally unknown. In this study, we show that the in vivo hormonal control of the gene expression strongly differs in the three tissues.

In the liver, insulin, glucocorticoids, and thyroid hormones were required for the normal induction of aldolase $B$ mRNA synthesis in animals refed the maltose-rich diet. Neither diabetic, nor thyroidectomized, nor adrenalectomized animals refed the maltose-rich diet could express aldolase B mRNA in their liver, despite adequate food consumption. When refed animals were given the missing hormone, the level of hybridizable material returned to control values, but no induction of the mRNA occurred when fasted rats were given any hormone without dietary carbohydrate. Thus, insulin, glucocorticoids, and thyroid hormones exerted a "permissive" effect on the induction of liver aldolase B mRNA synthesis in maltose-fed rats. Consequently, both the hormones and the glycolytic substrates were required for the full induction of the mRNA in the liver. These results at the pretranslational level confirm and extend the results of Adelman et al. regarding the role of glucocorticoids on the dietary induction of liver aldolase B activity (9).

In the small intestine of maltose-fed rats, insulin and thyroid hormones, but not glucocorticoids, were required for the full induction of the mRNA. This was not a result of defective absorption of the carbohydrate, since intestinal $a b$ sorption of sugars is not only normal but even enhanced in experimental diabetes (31). In the kidney, none of the hormonal modifications tested gave rise to any change in mRNA induction.

Thus, glucocorticoids were required for the mRNA synthesis in liver but not in kidney and small intestine. Insulin and thyroid hormones were required in both liver and small

Table II. Dietary Induction and Hormonal Control of Aldolase B Gene Expression

\begin{tabular}{|c|c|c|c|c|c|c|}
\hline \multirow[b]{2}{*}{ Organs } & \multirow[b]{2}{*}{ Carbohydrates } & \multirow{2}{*}{$\begin{array}{l}\text { Dietary } \\
\text { induction }\end{array}$} & \multirow{2}{*}{$\begin{array}{l}\text { Glucagon } \\
\text { and cAMP inhibition }\end{array}$} & \multicolumn{3}{|c|}{ Hormones required for dietary induction } \\
\hline & & & & Insulin & Thyroid hormones & Corticosterone \\
\hline \multirow[t]{2}{*}{ Liver } & $+\begin{array}{l}\text { Glucose } \\
\text { maltose }\end{array}$ & + & + & + & + & + \\
\hline & Fructose & + & + & 0 & + & + \\
\hline \multirow[t]{2}{*}{ Kidney } & $+\underset{\text { maltose }}{\text { Glucosè }}$ & 0 & 0 & 0 & 0 & 0 \\
\hline & Fructose & + & ND & 0 & 0 & 0 \\
\hline \multirow[t]{2}{*}{ Small intestine } & $+\begin{array}{l}\text { Glucose } \\
\text { maltose }\end{array}$ & + & 0 & + & + & 0 \\
\hline & Fructóse & + & ND & 0 & + & 0 \\
\hline
\end{tabular}

ND, not determined. 
intestine but not in the kidney of maltose-fed rats. It is worth noting that hormone receptors are present in tissue even where the hormone is not required for gene expression: receptors for glucocorticoids exist in the kidney (32) and small intestine (33); receptors for insulin (34) and thyroid hormones (35) are present in the kidney. However, the concentration of receptors required for hormone action in the different tissues is not well known: if the number of receptors present is below the level required for hormone action, one may expect the induction of the mRNA to be independent of the hormone tested, as observed in this study.

As stated above, aldolase $B$ can be regarded as a key enzyme of fructose metabolism because of its highly specific activity toward the substrate F1P. Therefore, the regulation of the gene expression in fructose-fed animals deserves particular attention. A major discrepancy was found between the two dietary conditions tested: diabetic animals expressed aldolase B mRNA in the liver and small intestine when refed the fructose-rich but not the maltose-rich diet. This is in accord with previous in vivo observations that the use of fructose is unimpaired in liver slices of diabetic rats $(36,37)$, and that fructose feeding can induce another glycolytic enzyme, L-type pyruvate kinase, to normal levels in diabetic rats (38). These results suggest an insulin-independent action of fructose on gene expression.

We have previously shown that the level of aldolase B mRNA in the liver of animals refed a protein-rich diet is very low and similar to that observed in fasted rats (16). Thus, despite their opposite effects on insulin release, both starvation and a protein-rich diet appear to alter the mRNA level in the same way. Indeed, these two very different nutritional situations share a major hormonal feature, namely, hyperglucagonemia. Therefore, we tested the hypothesis that glucagon and cAMP play a role in regulating the level of aldolase B mRNA synthesis in the liver, kidney, and small intestine. In the liver, both rapid and long-acting glucagon caused a dramatic decrease of the mRNA, which fell to fasting values in animals refed either carbohydrate-rich diet. Both cAMP, the second messenger of glucagon, and theophylline, an inhibitor of phosphodiesterase activity, were found to mimic the action of glucagon, which effects change in both pharmacological doses and physiological doses, because arginine, a powerful physiological agent of glucagon release (39), significantly reduces the level of the mRNA in the liver. In addition, the induction of the mRNA is abolished when glucagon is administered at very low doses, corresponding to the glucagon release by an isolated rat pancreas perfused in the absence of glucose (40). Despite very high levels of IRI in the plasma of both glucagon- and cAMPtreated animals, neither endogenous nor exogenous insulin administered together with these substances could reverse the effects of either glucagon or cAMP in our experiment. On the other hand, neither glucagon nor cAMP could alter the mRNA induction in the kidney and small intestine of carbohydratefed rats, despite the presence of receptors for enteroglucagon in gut and the existence of several adenylate cyclase activating systems in both the kidney and small intestine. Therefore, glucagon may play a role in regulating the level of aldolase B mRNA synthesis in the liver, but not in the kidney and small intestine, of both fasted and protein-fed animals, as previously described for another glycolytic enzyme mRNA, L-type pyruvate kinase (41), and for certain lipogenic enzymes, including malic enzyme (42). Moreover, since glucagon release is con- stantly increased in severe diabetes (43-45), our results raise the question of whether the low level of aldolase B mRNA in diabetes is due to the lack of insulin only, or whether the excess of glucagon also plays a part in the suppression of the specific mRNA synthesis.

In conclusion, this study shows that the in vivo regulation of aldolase B gene expression strongly differs in the liver, kidney, and small intestine. In the liver, the synthesis of the mRNA requires the presence of dietary carbohydrates, the cessation of glucagon release, and the presence of permissive hormones, including insulin for glucose and maltose-fed rats but excluding it for fructose-fed animals. In the small intestine, the presence of both dietary carbohydrates and insulin (for maltose-fed rats) is required, but glucagon and cAMP are devoid of any effect. In the kidney, the synthesis of the mRNA is constitutive, poorly modulated by the diet, and unaffected by hormonal status.

\section{Acknowledgments}

We thank Dr. Fanny Schapira who initiated the study of aldolase B in our laboratory. Her helpful discussions and comments were greatly appreciated. We thank Dr. Jacques Schmitz for his stimulating discussions, Miss Catherine Dalleu for typing the manuscript, and Mr. Alan Strickland for his help in preparing it.

This work was supported by INSERM and the Fonds d'Etudes du Corps Médical des Hôpitaux de Paris.

\section{References}

1. Hers, H. G., and T. Kusaka. 1953. Le métabolisme du fructose 1 phosphate dans le foie. Biochim. Biophys. Acta. 11:427-437.

2. Kaletta-Gmunder, U., H. Wolf, and F. Leuthard. 1957. Über Aldolasen: Chromatographische Trennung von 1-Phosphofructaldolase und Diphosphofructaldolase der Leber. Helv. Chim. Acta. 40:10271032.

3. Schapira, F. 1961. L'activité fructose 1 phospho aldolasique des tissus de mammifêres. Bull. Soc. Chim. Biol. 43:1357-1387.

4. Peanasky, R. T., and H. A. Lardy. 1958. Bovine liver aldolase. J. Biol. Chem. 233:365-373.

5. Blostein, R., and W. I. Rutter. 1963. Comparative studies of liver and muscle aldolase. J. Biol. Chem. 238:3280-3285.

6. Rajkumar, T. U., B. M. Woodfin, and W. J. Rutter. 1966. Carbohydrate metabolism. Methods Enzymol. 9:491-498.

7. Schapira, F., and Y. Nordmann. 1969. Présence de trois types d'aldolase dans le foie humain. Clin. Chim. Acta. 26:189-195.

8. Schapira, F. 1981. Resurgence of fetal isozymes in cancer: study of aldolase, pyruvate kinase, lactic dehydrogenase and b-hexosaminidase. Isozymes Curr. Top. Biol. Med. Res. 5:27-75.

9. Adelman, R. C., P. D. Spolter, and S. Weinhouse. 1966. Dietary and hormonal regulation of enzymes of fructose metabolism in rat liver. J. Biol. Chem. 241:5467-5472.

10. Heinz, F. 1968. Enzyme des Fructosestoffwechsels. HoppeSeyler's Z. Physiol. Chem. 349:399-404.

11. Sillero, M. A. G., A. Sillero, and A. Sols. 1969. Enzymes involved in fructose metabolism in liver and the glyceraldehyde metabolic cross roads. Eur. J. Biochem. 10:345-349.

12. Mavrias, D. A., and R. J. Mayer. 1973. Metabolism of fructose in the small intestine. The effect of fructose feeding on fructose transport and metabolism in rat small intestine. Biochim. Biophys. Acta. 291:531-537.

13. Stifel, F. B., N. S. Rosensweig, D. Zakim, and R. H. Herman. 1968. Dietary regulation of glycolytic enzymes. Adaptative changes in rat jejunum. Biochim. Biophys. Acta. 170:221-227.

14. Rosensweig, N. S., F. B. Stifel, R. H. Herman, and D. Zakim. 1968. The dietary regulation of the glycolytic enzymes. Adaptative changes in human jejunum. Biochim. Biophys. Acta. 170:228-234. 
15. Rosensweig, N. S., F. B. Stifel, D. Zakim, and R. H. Herman. 1969. Time response of human jejunal glycolytic enzymes to a high sucrose diet. Gastroenterology. 57:143-146.

16. Weber, A., J. Marie, D. Cottreau, M. P. Simon, C. Besmond, J. C. Dreyfus, and A. Kahn. 1984. Dietary control of aldolase B and L-type pyruvate kinase mRNAs in rat. J. Biol. Chem. 259:1798-1802.

17. Simon, M. P., C. Besmond, D. Cottreau, A. Weber, P. Chaumet-Riffaud, J. C. Dreyfus, J. Sala Trepat, J. Marie, and A. Kahn. 1983. Molecular cloning of cDNA for rat L-type pyruvate kinase and aldolase B. J. Biol. Chem. 258:14576-14584.

18. Farris, E. J., and J. O. Griffith. 1949. The Rat in Laboratory Investigation. J. B. Lippincott Co., Philadelphia. 439-441, 444.

19. Mahmood, H. A., P. J. Wood, and V. Marks. 1978. The effect of induced hyperglucagonemia on the Zucker fatty rat. Diabetologia. 14:405-412.

20. Tabata, Y., and T. M. S. Chang. 1982. Intermittent vascular access for extracorporeal circulation in conscious rats: a new technique. Artif. Organs (Cleve.). 6:213-215.

21. Kahn, A., D. Cottreau, D. Daegelen, and J. C. Dreyfus. 1981. Cell-free translation of messenger RNAs from adult and fetal human muscle. Characterization of neosynthesized glycogen phosphorylase, phosphofructokinase and glucose phosphate isomerase. Eur. J. Biochem. 116:7-12.

22. Bishop, J. O., M. Rosbash, and D. Evans. 1974. Polynucleotide sequences in eukaryotic DNA and RNA that form ribonucleaseresistant complexes with polyuridylic acid. J. Mol. Biol. 85:75-86.

23. Bailey, J. M., and N. Davidson. 1976. Methylmercury as a reversible denaturating agent for agarose gel electrophoresis. Anal. Biochem. 70:75-85.

24. Thomas, P. S. 1980. Hybridization of denatured RNA and small DNA fragments transferred to nitrocellulose. Proc. Natl. Acad. Sci. USA. 77:5201-5205.

25. Tsutsumi, K. I., T. Mukai, S. Hidaka, H. Miyahara, R. Tsutsumi, T. Tanaka, K. Hori, and K. Ishikawa. 1983. Rat aldolase isozyme gene. Cloning and characterization of cDNA for aldolase B messenger RNA. J. Biol. Chem. 258:6537-6542.

26. Besmond, C., J. C. Dreyfus, C. Gregori, M. Frain, M. M. Zakin, J. Zala Trepat, and A. Kahn. 1983. Nucleotide sequence of a cDNA clone for human aldolase B. Biochem. Biophys. Res. Commun. 117:601-609.

27. Crossley, J. M., and I. MacDonald. 1970. The influence in male baboons of a high sucrose diet on the portal and arterial levels of glucose and fructose following a sucrose meal. Nutr. Metab. 12: 171-178.

28. Topping, D. L., and P. A. Mayes. 1971. The concentration of fructose, glucose and lactate in the splanchnic blood vessels of rats absorbing fructose. Nutr. Metab. 13:331-338.

29. Schapira, F., D. Delain, and Y. Lacroix. 1971. Multiple molecular forms of aldolase in fetal liver cell cultures: action of dexamethasone. Enzyme (Basel). 12:545-552.
30. Guguen-Guillouzo, C., L. Tichonicky, M. F. Szajnert, F. Schapira, and J. Kruh. 1978. Changes in some chromatin and cytoplasmic enzymes in primary cultures of adult rat hepatocytes. Biol. Cell. 31:225-234.

31. Hopfer, U. 1975. Diabetes mellitus: changes in the transport properties of isolated intestinal microvillous membranes. Proc. Natl. Acad. Sci. USA. 72:2027-2031.

32. Funder, J. W., D. Fedman, and I. S. Edelman. 1973. Glucocorticoid receptors in rat kidney: the binding of tritiated dexamethasone. Endocrinology. 92:1005-1011.

33. Henning, S. J., P. L. Ballard, and N. Kretchmer. 1975. A study of the cytoplasmic receptors for glucocorticoids in intestine of pre- and postweanling rats. Proc. Natl. Acad. Sci. USA. 250:2073-2079.

34. Williams. R. H. 1981. The endocrine pancreas and diabetes mellitus. In Textbook of Endocrinolgy. R. H. Williams, editor. W. B. Saunders Co., Philadelphia. 742-745.

35. Oppenheimer, J. H., D. Koerner, H. L. Schwartz, and M. I. Surks. 1972. Specific nuclear triiodothyronine binding sites in rat liver and kidney. J. Clin. Endocrinol. Metab. 35:330-334.

36. Miller, M., W. R. Drucker, J. E. Owens, J. W. Craig, and H. Woodward, Jr. 1952. Metabolism of intravenous fructose and glucose in normal and diabetic subjects. J. Clin. Invest. 31:115-125.

37. Renold, A. E., A. B. Hastings, and F. B. Nesbett. 1954. Studies on carbohydrate metabolism in rat liver slices. Utilization of fructose and glucose by liver from normal and diabetic animals. J. Biol. Chem. 209:687-692.

38. Sillero, A., M. A. G. Sillero, and A. Sols. 1969. Regulation of the level of key enzymes of glycolysis and gluconeogenesis in liver. Eur. J. Biochem. 10:351-354.

39. Gerich, J. E., M. A. Charles, and G. M. Grodsky. 1976. Regulation of pancreatic insulin and glucagon secretion. Annu. Rev. Physiol. 38:353-388.

40. Gerich, J. E., M. A. Charles, and G. M. Grodsky. 1974. Characterization of the effects of arginine and glucose on glucagon and insulin release from the perfused rat pancreas. J. Clin. Invest. 54:833841.

41. Munnich, A., J. Marie, G. Reach, S. Vaulont, M. P. Simon, and A. Kahn. 1984. In vivo hormonal control of L-type pyruvate kinase gene expression. J. Biol. Chem. 259:10228-10231.

42. Winberry, L. K., J. M. Morris, J. E. Fisch, M. J. Glynias, R. A. Jenik, and A. G. Goodridge. 1983. Molecular cloning of cDNA sequences for avian malic enzyme. J. Biol. Chem. 258:1337-1342.

43. Gerich, J. E., M. Lorenzi, and D. M. Bier. 1975. Prevention of human diabetic ketoacidosis by somatostatin: evidence for an essential role of glucagon. N. Engl. J. Med. 292:985-989.

44. Raskin, P., and R. H. Unger. 1978. Hyperglucagonemia and its suppression: importance in the metabolic control of diabetes. $N$. Engl. J. Med. 299:433-436.

45. Unger, R. H., and L. Orci. 1975. Hypothesis: the essential role of glucagon in the pathogenesis of diabetes mellitus. Lancet. 1:14-16. 